\title{
Pathya-Apathya- A Peculiarity of Ayurveda
}

\author{
Garud Sandeep ${ }^{1}$, Chaudhary Anubha ${ }^{2}$, Kotecha Mita ${ }^{3}$ \\ ${ }^{1,2}$ P.G. Scholar, Department of Dravyaguna Vigyana, National Institute of Ayurveda, Jaipur \\ ${ }^{3}$ Professor, H.O.D., Department of Dravyaguna Vigyana, National Institute of Ayurveda, Jaipur \\ Corresponding author:- Dr. Sandeep Garud \\ 4/770, Sector 4, Jawahar Nagar, Jaipur, Rajasthan, India.
}

\begin{abstract}
-
Ayurveda is not merely a medical science. It is a complete life science. The first aim of Ayurveda is to maintain the health of a healthy person so that no diseases should manifest. Treatment of diseases is the second aim of Ayurveda. To maintain the health of a healthy person Acharyas had described various dos and don'ts such as Ritucharya (seasonal regime), Dinacharya (diurnal regime) etc. The concept of Pathya (wholesome)and Apathaya (unwholesome) is one such concept. Apart from being a part of regime of healthy living, Ácharyas had also extended the concept of Pathya (wholesome)and Apathaya (unwholesome) as a part of the treatment of the diseases. This indicates the importance of Pathya (wholesome)and Apathaya (unwholesome) in Ayurveda. The concept of Pathya (wholesome)and Apathaya (unwholesome) is the peculiarity of Ayurveda.
\end{abstract}

Keywords- Ayurveda, Pathya, Apathaya, Healthy living.

\section{INTRODUCTION-}

The aims and objectives of Ayurvedaare to maintain the health of a healthy person and to cure the diseases of the patients ${ }^{1}$. As evident the first and foremost aim of Ayurveda is preventive in nature rather than curative. It signifies that "prevention is better than cure". To maintain the health, Ayurveda laid many basic principles like Ritucharya (seasonal regime), Dinacharya (diurnal regime) etc. The concept of Pathya (wholesome) and Apathya(unwholesome) is the peculiarity of Ayurveda to fulfill its aims and objectives.

The word Pathya derives its origin from root word Patha which literally means a way or channel.Pathya(wholesome) and Apathya (unwholesome) are defined as the substance or regime which do not adversely affect the body and mind are regarded as Pathya (wholesome); those which adversely affect them are considered to be Apathya (unwholesome) ${ }^{2}$. As evident from above definition, Pathya (wholesome) and Apathya(unwholesome)include both material substances and specific regimes but in general these words had been particularly used for food articles in the texts of Ayurveda.

Charak had stated that wholesome food is one of the causes for the growth and wellbeing of humans while unwholesome food is the root of all diseases ${ }^{3}$. Charak had counted food first in the series of three supporting pillars of life along with sleep and controlled sexual activity ${ }^{4}$. Sushrut had further supported the fact by stating that food is the cause of vitality, strength, complexion and Oja ${ }^{5}$. 
Garud Sandeep ${ }^{1}$,International Journal of Ayurvedic \& Herbal Medicine 7(4) July.-Aug.2017 (2635-2642)

\section{SYNONYMS-}

\subsection{Pathya-}

Satmya,Swasthhitakara,Upshaya,Swavasthaparipaalaka,HitaAhara,Swasthaaurjaskara,Sharmakara,Dhatua virodhi,Sukhaparinaamkara,DhatuSaamyakara ${ }^{6}$

2.2Apathya-Asatmya,SwasthaAhitkara,Anupashaya,Ahitkara,AsukhaParinaamakara,

Ashrmakara,

Dhatuasamyakara.

\section{ANTIQUITY OF PATHYA \&APATHYA-}

History deals with the past. It is a guideline for development in any field of the life. The past experience about drugs/ food articles is of great help with regards to their quality, individuality, uniqueness etc. thus making it more fruitful for future generations.

3.1 Veda-Vedasare the earliest known documentation, the sacred literature of India. Various evades about Pathya \&Apathya are present in Veda right from Rigaveda e.g. Soma is the functional part of wholesome food which is a powerful medicine of all diseases. Wholesome food acts as a medicine and it should be strictly followed (Rigveda 8/73/17).

YajurvedaexplainedmanycerealsandfoodingredientslikeMasha(Phaseolus

moongo

Linn.),Tila(Sesamum indicum Linn.),Moodga(Phaseolus radiatus Linn.),Priyangu (Setaria italic Beauv.),Shyamaka (Echinochloa frumentacea),Neevara (Hygroryza aristata Nees.),Godhuma(Triticum sativum Lam.),Masoora(Lens culinaris Medic.)etc.Yajurveda states that water, food, air etc. when purified by Yajna Karma acts as medicine. (Yajurveda 18/12).

Atharveda states that a person who maintains Agni(fire), Jala (water), Vayu(air)and Prithavi(earth) by wholesome food and celibacy becomes energetic and healthy. He progresses towards the transcendent state attained as a result of being released from the cycle of rebirth (Atharveda Dwityakanda 28/5). In Atharveda,somecerealslikeVirihi(Oryza sativa Linn.),Yava(Hordeum vulgare Linn.),Tila (Sesamum indicum Linn.),Masoora (Lens culinaris Medic.),Masha (Phaseolus moongo Linn.)etc. had been described (Atharveda Shastha kanda 2/140).

3.2 Ramayana- Payasa(rice pudding) in creases the power of reproduction and provides the wealth and health, thus is good and Pathya for human (Valmiki Ramayana 1/16/19).

3.3 Bhagwad Geeta- Food has been classified as Saatvika, Rajasa and Tamasa in nature.

Saatvika food increases life span, purifies the mind and soul and provides health, happiness and strength. This type of nourishing food is sweet, juicy, fatty and palatable.

Rajasa foods are too bitter, too sour, salty, pungent, and dryand hot. Such food scausep a in, distress, and disease.

Tamasa foods are food that are being cooked more than three hours before consumption, which is tasteless, decayed, decomposed and unclean (Bhagwad Geeta 17/7-10).

3.4 Hatha Yoga- Hatha Yoga Samhitade scribed Pathya Ahara for YogaShishya (disciple of Yoga). Ahara (food) for Yoga Shishya (student)should include Godhuma (Triticum sativum Lam.),Shali-Shashtika (Oryza sativa Linn.),Yava(Hordeum vulgare Linn.), Shobhananna (Shyamaka, Nivara,etc), Ksheera(milk), Aajya (clarified butter), Navneeta (freshly extracted butter),Sita (sugar),Madhu (honey), Shunthi (Zingiber officinale Rosc.), Patola (Trichosanthes dioica Roxb.), Panchashaka (Jeevanti (Leptadenia reticulate W. \& A.),Vastuka (Chenopodium album Linn.), Matsyakshi (Enhydra fluctuans Lour.), Meghanada (?),Punarnava 


\section{Garud Sandeep ${ }^{1}$,International Journal of Ayurvedic \& Herbal Medicine 7(4) July.-Aug.2017 (2635-2642)}

(Boerhaavia diffusa Linn.),Mudga (Phaseolus radiatus Linn.), Aadhaki (Cajanus indicus Sperng.)and Divyodaka (Hathayoga Samhita 1/59-63).

\section{IMPORTANCE OF PATHYA \&APATHYA-}

The importance of Pathya(wholesome)and Apathya(unwholesome) in Ayurveda can be deduced from the fact that Charak had stated Pathya(wholesome)as a synonym for treatment ${ }^{7}$. Charak stated that when channels of circulation become hard by aggravated and vitiated Dosha, Pathya(wholesome) helps to soften the Srotasa (channels of circulation) and Doshaalleviation ${ }^{8}$.Charak had elaborately described the concept of Pathya(wholesome)and Apathya(unwholesome). He had given a general list of Pathya (wholesome) and Apathya Dravya(unwholesome) along with specific Pathya(wholesome)and Apathya Dravya(unwholesome)for patients and Sansarjana Karma(specific food regime) for patients who have undergone Panchkarma Therapy.

Further, Sushrut had specifically written a chapter named Hita-Ahitiya Aadhyay in Sutra Sthan.

Kashyap explored the medicinal potential of Aahar (food) along with its prophylactic value of maintaining health. Kashyap stated that food is the best medicine. No drug can match the benefits of food in diseased state. Only wholesome food can keep a person healthy ${ }^{9}$.

Harita stated the importance of Pathya(wholesome)and Apathya(unwholesome)by stating that if a personignorestheconceptofPathya-ApathyaanddevourApathya(unwholesome), illness will never leave the body. Hencepers on should use Pathya (wholesome) according to his/her physical and pathological condition regularly.Even in the absence of medicine, if patienttakes only Pathya (whole some) according to disease he will become healthy, but even if patienttakesmore and regular medicine and avoid Pathya Aharapre scribed by physician ,he will neverbecomehealthy ${ }^{10}$.

In Yogaratnakara, it is said that for the treatment of diseases etiology, drug treatment and Pathya (wholesome) are three important factors which should be studied thoroughly before starting the treatment. Judicious planning of treatment by proper understanding of these three factors always yields a successful eradication of disease. Yogaratnakara uses the metaphor of Ankura (seedling) for progressive form of disease. This Ankura (seedling) will dry and be destroyed if it is not nourished by water; similarly disease will be destroyed if a patient does not consume Apathya Ahara(unwholesome food $)^{11}$.

Vaidya Lolimbraja indicated the importance of Pathya Aahar(wholesome food)by stating that if a patient intakes wholesome food then there is no need of medicine and if a patient continuously consumes unwholesome food then also there is no need of medicine. In the latter case, medicine will not be effective $^{12}$.

Charak had also given equal importance to Pathya Vihar (wholesome routine) alongwith Pathya Aahar(wholesome food) for maintenance of health. As Charak has stated that inconditionsofChinta(anxiety),Shoka(sorrow), Krodha(anger),DukhaShaiya(uncomfortable bed)andRatrijagarana(insomnia), eventhesmallamountofPathyaAhara(wholesome notdigested,thushavegivenequalimportance to both Pathya Ahara and Vihara ${ }^{13}$.

Bhela Samhita also explains about merits of Pathya and demerits of Apathya in the Sutrasthana. Pathya Ahara nourishes all Dhatus (body elements) and Srotasa (channels of circulation) leading to completenutrition of body. Pathya Ahara also helps to detoxify the body by getting rid of vitiated Dosha. Contrary to this, Apathya Ahara helps in vitiation of Vata etc. Doshas. Hence for maintenance of health and treating diseases Pathya Ahara should be consumed ${ }^{14}$. 
Garud Sandeep ${ }^{1}$,International Journal of Ayurvedic \& Herbal Medicine 7(4) July.-Aug.2017 (2635-2642)

\section{GENERAL PATHYAAND APATHYA-}

Acharya Charak indicated some food articles which should always be consumed by healthy persons. These food articles include Shashtika (variety of rice), Shali (variety of rice), Mudga (Phaseolus radiatus Linn.), Saindhav, Amalaka (Emblica officinalis Gaertn.), rain water, Ghee (butter), meat of animals dwelling in arid climate and honey ${ }^{15}$. Similarly, Acharya Charak had also indicated some food articles which should be avoided by healthy persons. Such food articles are Vallura (dried meat), dried vegetables, lotus rhizome and stalk and one should never consume meat of diseased animals ${ }^{16}$.

\begin{tabular}{|c|c|c|}
\hline Varga & Pathya & Apathya \\
\hline ShukaDhanya & $\begin{array}{c}\text { Rakta shali, Shastika and types of } \\
\text { Shastika.Godhuma. Yava }\end{array}$ & Yavaka \\
\hline Shami Dhanya & $\begin{array}{c}\text { Mudga,Masura,Mangalya,Chana } \\
\text { ka,Aadhaki, }\end{array}$ & Masha \\
\hline Mansa Varga & $\begin{array}{c}\text { Ajameda, Ena (antelope), Godha } \\
\text { (inguana), Rohit Matshya,Chuluki } \\
\text { (Gangetic dolphin), VasaJangala } \\
\text { Mansa etc }\end{array}$ & $\begin{array}{l}\text { Go mansa, Kankapota mansa (young } \\
\text { dove), frog, Chilchim fish, Kumbhir } \\
\text { (crocodile) fat, Kakamudga (water } \\
\text { foul) fat Chataka (snarrow) fat }\end{array}$ \\
\hline Shaka Varga & $\begin{array}{c}\text { Vastuka,Patha, } \\
\text { Sunishnaka,Jeevanti,Tanduliyaka, } \\
\text { Mandukaparni, Kushmanda, } \\
\text { Patola } \\
\text { KakmacRajakshawaka,Nadi }\end{array}$ & $\begin{array}{c}\text { Sarshapa Shaka, Kusumbha } \\
\text { Shaaka etc. }\end{array}$ \\
\hline Phala Varga & $\begin{array}{c}\text { Dadima, } \\
\text { Aamlaka,Haritaki,Vibhitaki,Mridvika, }\end{array}$ & Nikucha (Atrocarpus lakoocha) \\
\hline Harita Varga & $\begin{array}{c}\text { Sringawera, Baal moolak, } \\
\text { Sursa, Haridra, } \\
\text { Dhanyaka,Yavani, Methika }\end{array}$ & \\
\hline Madya Varga & $\begin{array}{l}\text { Purana Madya, Madhwika, } \\
\text { Matravata Pana }\end{array}$ & \\
\hline Jala & Eindra Jala, Shrita Sheeta jala, & Kalushita (unclean) Jala \\
\hline Gorasa varga & $\begin{array}{l}\text { Go dugdha, Aja dugha, } \\
\text { Mahisha Dugdha, Go- } \\
\text { Ghee,Takra,Navneeta. }\end{array}$ & $\begin{array}{c}\text { Avi (sheep) Dugdha, Aavika } \\
\text { (Sheep) Ghrita }\end{array}$ \\
\hline Ikshu Varga & Guda, Sharkara, Madhu & Phanita (treacle) \\
\hline Kritanna Varga & $\begin{array}{c}\text { Manda,Peya,krishara, Audana, } \\
\text { Yusha. Saktu }\end{array}$ & \\
\hline Aharayogina Varga & $\begin{array}{c}\text { Tail, Vasa, Hingu, Pippali, Saindhava } \\
\text { Lavana }\end{array}$ & \\
\hline
\end{tabular}




\begin{tabular}{|c|c|c|}
\hline Vihara & Brahmcharya, Nivatashyana, \\
& Ushodaka Snana,NishaSwapana, & \\
Vyaayaama, Vegavidhaarna, & \\
& Maatraavata Asana, Kaala bhojana, & \\
& Avhyanaga,Bhojanamjeerne. & \\
\hline
\end{tabular}

\section{GENERAL PARAMETERS TO DECIDE PATHYA-APATHYA-}

Corns and grains, one year after their harvesting are wholesome. Old corns and grains are mostly not unctuous while fresh ones are heavy to digest. Corns and grains which take a shorter time for cultivation as well as for harvesting are easy to digest than those taking longer time. De-husked pulses are easy to digest $\mathrm{t}^{17}$.

Meat of animals who have died a natural death, who are emaciated or dried up after death, who are fatty in excess, who are old, who are too young, who are killed by poisonous arrows, who gaze in a land not commensurate with their natural habitat and who are bitten by snakes and tigers etc. are unwholesome. Otherwise, meat is wholesome, nourishing and strength promoting ${ }^{18}$.

Vegetables infested with insects, exposed to the wind and the sun for long time, dried up, old and unseasonal are wholesome. When they are cooked without fat and residual water after boiling is not filtered out, vegetables become unwholesome for use ${ }^{19}$.

Fruits which are old, unipe, afflicted by insects and serpents, exposed to snow or sun for long, growing in the land and season other than the normal habitat and time and putrefied are unwholesome ${ }^{20}$.

\section{DIFFERENT PATHYA KALPANA-}

Various Pathya Kalpana like Peya, Vilepi, Yavagu had been described by Acharyas. These Kalpanas (preparations) are generally used in different diseases according to state of disease and capacity to digest the food in that disease. These Kalpana(preparations) helps in stimulating digestive fire. Thus, it will also avoid formation of Ama which is often triggered when Agni (digestive fire) is hampered.

\subsection{Pathya Kalpana and Their Uses ${ }^{21}$ :}

\begin{tabular}{|c|c|c|}
\hline Pathya Kalpana & Method for preparation & Uses \\
\hline 1. Manda & $\begin{array}{c}\text { The filtered liquid portion obtained after boiling one } \\
\text { Carminative, Digestive part of rice and fourteen parts of } \\
\text { water }\end{array}$ & $\begin{array}{c}\text { Carminative, digestive } \\
\text { 2. Peya }\end{array}$ \\
$\begin{array}{c}\text { One part of rice and fourteen parts of water, boiled into } \\
\text { Quickly digestible, Stops loose watery consistency }\end{array}$ & $\begin{array}{c}\text { Quickly digestible, stops } \\
\text { loose motions, Nourishes } \\
\text { the tissues. }\end{array}$ \\
\hline 3. Vilepi & $\begin{array}{c}\text { One part of rice and four parts of water, cooked into } \\
\text { Strengthening, Nourishing, Good for thick paste }\end{array}$ & $\begin{array}{c}\text { Strengthening, } \\
\text { nourishing, good for } \\
\text { heart, Delicious, Diuretic }\end{array}$ \\
\hline 4. Yavagu & One part of grain rice etc. and six parts of water, & Strengthening, nourishing \\
\hline
\end{tabular}




\section{PRACTICAL APPLICATION OF CONCEPT OF PATHYA-APATHYA-}

8.1 Pathya-Apathya in a particular season: Acharyahad described specific Pathya-Apathya for every season. The practice of Pathya-Apathya as per season will improve overall health e.g. in winter season meat of aquatic and marshy animals and burrow dwelling anials should be consumed. Other wholesome food articles for winter season include preparations of cow milk, cane juice, fat, oil, new rice etc. On the other hand dieting and intake of gruel should be avoided. In Vihara, fomentation and warm clothes are wholesome to practice $^{22}$.

8.2 Concept of Kritanna Varga:All these benefits of Pathya Aahara can be ripped off with the help of Kritanna Varga described in various ancient texts. Properties of these Kritanna differ from each other depending upon the method of preparation even if material used is the same. In case of Manda, Peya, Yavagu and Vilepi, the amount of water used for cooking and then amount of liquid and solid content is different for each of them. These Kalpana become easy to digest according to their state and attain various physiological actions as well. Thus, these can be prescribed for patient as a meal.

8.3 Pathya-irrespective of disease condition:These Pathya Ahara are described specific to a particular disease condition. According to Bhavaprakasha taking ginger and salt before food is always good and it enhances Agni(digestive fire) ${ }^{23}$. Taste, clears tongue and throat. Charaka and Vagbhata also describe some regularly consumable food articles. Rakta shali, Mudga, Rain water, Saindhava (rock salt), Jivanti, meat of Aina, Godha, Rohita Matsya, cow's ghee, cow's milk, Tila Taila, ginger, grapes, pomegranate and sugar are considered as most conducive among food articles.

8.4 Pathya-for specific disease condition:Disease specific Pathya (wholesome diet/ foods to be consumed) and Apathya (unwholesome diet/ foods to be avoided) are explained in various classical texts like Charaka Samhita, Sushruta Samhita, Ashtangahridaya etc. but there are detailed descriptions about them in other texts like Sharangdhara Samhita, Pathyapathya Vibodhika, Bhaishajyaratnavali etc.e.g.

\subsubsection{Madhumeha (Diabetes mellitus):}

\begin{tabular}{|c|c|c|}
\hline Item & Pathya & Apathya \\
\hline Cereals & $\begin{array}{c}\text { Barley, special variety of } \\
\text { grain (sanvaka, kodrava), } \\
\text { wheat }\end{array}$ & Freshly harvested grains, rice \\
\hline Pulses & $\begin{array}{c}\text { Green gram (Mudga), } \\
\text { Kulattha, pigeon pea } \\
\text { (Arahara), Alasi, chickpea } \\
(\text { cana })\end{array}$ & Black gram $($ Udada $)$ \\
\hline $\begin{array}{l}\text { Fruits and } \\
\text { vegetables }\end{array}$ & $\begin{array}{l}\text { Patola }, \text { bitter gourd } \\
\text { (karavellaka), amalaki, } \\
\text { haridra, kapittha, black } \\
\text { pepper }\end{array}$ & Sweet fruits, Potato etc. \\
\hline Other & Honey, betel nut, rock salt & $\begin{array}{l}\text { Milk, curd, butter milk, clarified butter, oil, } \\
\text { jaggery, alcohol, sugarcane products, betel, } \\
\text { eating before digestion of previous food, } \\
\text { incompatible food }\end{array}$ \\
\hline
\end{tabular}

\subsubsection{Sandhivata (Osteoarthritis):}


Garud Sandeep ${ }^{1}$,International Journal of Ayurvedic \& Herbal Medicine 7(4) July.-Aug.2017 (2635-2642)

\begin{tabular}{|c|c|c|}
\hline Item & Pathya & Apathya \\
\hline Cereals & Wheat, rice & $\begin{array}{c}\text { Special variety of rice } \\
\text { (kodrava, sanvaka) }\end{array}$ \\
\hline Pulses & Black gram (udada), kulattha & $\begin{array}{c}\text { Peas (matar), chickpea } \\
\text { (cana), pigeon pea (arahara), } \\
\text { green gram (mudga) }\end{array}$ \\
\hline $\begin{array}{c}\text { Fruits \& } \\
\text { vegetables }\end{array}$ & $\begin{array}{c}\text { Patola, shigru, brinjal, garlic, pomegranate, } \\
\text { mango, phalasa, lemon, jujube plum (badara, } \\
\text { bera), grapes }\end{array}$ & $\begin{array}{c}\text { Bitter gourd (karavellaka), } \\
\text { lotus stem }\end{array}$ \\
\hline Other & $\begin{array}{c}\text { Clarified butter, oil, sesame, milk, coconut } \\
\text { water, sour vinegar (kanji), tamarind (imali) }\end{array}$ & Jambu, betel nut \\
\hline
\end{tabular}

\section{DISCUSSION-}

Ayurveda has a holistic approach in health management. It gives due importance to food in the management of disease both as a causative factor (Apathya) and as a part of therapy (Pathya). As per Ayurveda, most of the ailments develop due to faulty eating habits so Ayurveda deals with the Pathya Vyavastha (planning of diet and dietetics) in a very scientific way. Day to day activities, seasonal regimes etc. also plays an important role in the maintenance of health and thus, had also been included in the concept of PathyaApathya by the Acharyas. The above described facts are about the general concept of Pathya-Apathya in Ayurveda. The specific Pathya-Apathya for a particular person may differ as Ayurveda believes in the concept of uniqueness of each and every individual ${ }^{24}$. The exact Pathya-Apathya for a particular person should be decided after analyzing Prakriti (body nature), Kalpana (preparation to be given), Kaal (time of intake of food), Matra (quantity) etc.

\section{CONCLUSION-}

Pathya is the one which keeps the person healthy, maintains normal body functions leads to proper functioning of the organs, nourishes the mind and intellect, prevents diseases and at the same time corrects the irregularities that may occur in the body. Thus, everyone should refrain from Apathya (unwholesome to body) and follow Pathya (wholesome to body) as prevention is better then cure.

\section{REFERENCES:-}

1. Agnivesh, Arthedashamahaamuliya Adhyaay, Sutra Sthan, Charak Samhita with Chakrapani Teeka, ed. Yadavji Trikam Ji, Ist edition, Chaukhambha Surbharti Prakashan, Varanasi, 2014, page- 187.

2. Agnivesh, Yajjapurushiya Adhyaay, Sutra Sthan, Charak Samhita with Chakrapani Teeka, ed. Yadavji Trikam Ji, Ist edition, Chaukhambha Surbharti Prakashan, Varanasi, 2014, page- 133.

3. Agnivesh, Yajjapurushiya Adhyaay, Sutra Sthan, Charak Samhita with Chakrapani Teeka, ed. Yadavji Trikam Ji, Ist edition, Chaukhambha Surbharti Prakashan, Varanasi, 2014, page- 129.

4. Agnivesh, Trieshniya Adhyaay, Sutra Sthan, Charak Samhita with Chakrapani Teeka, ed. Yadavji Trikam Ji, Ist edition, Chaukhambha Surbharti Prakashan, Varanasi, 2014, page- 74.

5. Sushrut, Annapaan Vidhi Adhyay, Sushrut Samhita with Nibandh Sangrah \& Nyay Chandrika Commentary, translator Keval Krishna Thakral, Ist edition, Vol. I, Chaukhambha Orientalia, Varanasi, 2014, page- 544.

6. Commentary by Chakrapani, Yajjapurushiya Adhyay, Sutra Sthan, Charak Samhita with Chakrapani Teeka, ed. Yadavji Trikam Ji, Ist edition, Chaukhambha Surbharti Prakashan, Varanasi, 2014, page133. 
7. Agnivesh, Rasaayan Adhyaay, Abhaya Aamalaki Rasaayan Paad, Chikitsa Sthan, Charak Samhita with Chakrapani Teeka, ed. Yadavji Trikam Ji, Ist edition, Chaukhambha Surbharti Prakashan, Varanasi, 2014, page- 376.

8. Agnivesh, Yonivyaapad Chikitsa, Chikitsa Sthan, Charak Samhita with Chakrapani Teeka, ed. Yadavji Trikam Ji, Ist edition, Chaukhambha Surbharti Prakashan, Varanasi, 2014, page- 649.

9. Kashyap,Amlapitta Chikitsaadhyay, editor Prof. P.V.Tiwari, Kashyap Samhita, $1^{\text {st }}$ edition, Varansi, Chaukhamba Vishvabharti, 1996, page- 468.

10. Harit, Aushadha Parigyan Vidhan, Tritya Sthan, editor Harihara Prashad Tipathi, Chaukhambha Krishnadas Academy, Varanasi, 2005, page- 173.

11. Anonymous, Jwarchikitsa, Yogaratnakara, editor P.V. Tiwari, Ist edition, Chaukhambha Vishvabharti, Varanasi, 2010, page- 286.

12. Lolimbaraja, Prathamo Vilasa, Vaidya Jeevana, editor Priyavrat Sharma, Chaukhambha Surbharti Prakashan, Varanasi, 2013, page- 6.

13. Agnivesh, Trividh Kukshiyam, Vimaan Sthan, Charak Samhita with Chakrapani Teeka, ed. Yadavji Trikam Ji, Ist edition, Chaukhambha Surbharti Prakashan, Varanasi, 2014, page- 238.

14. Bhel, Atyashitiya Adhyay, Bhel Samhita, editor Abhay Katyayan, Chaukhambha Surbharti Prakashan, Varanasi, 2009, page- 15.

15. Agnivesh, Matrashitiya Adhyaay, Sutra Sthan, Charak Samhita with Chakrapani Teeka, ed. Yadavji Trikam Ji, Ist edition, Chaukhambha Surbharti Prakashan, Varanasi, 2014, page- 38.

16. Agnivesh, Matrashitiya Adhyaay, Sutra Sthan, Charak Samhita with Chakrapani Teeka, ed. Yadavji Trikam Ji, Ist edition, Chaukhambha Surbharti Prakashan, Varanasi, 2014, page- 38.

17. Agnivesh, Annapaanvidhi Adhyaay, Sutra Sthan, Charak Samhita with Chakrapani Teeka, ed. Yadavji Trikam Ji, Ist edition, Chaukhambha Surbharti Prakashan, Varanasi, 2014, page- 171.

18. Agnivesh, Annapaanvidhi Adhyaay, Sutra Sthan, Charak Samhita with Chakrapani Teeka, ed. Yadavji Trikam Ji, Ist edition, Chaukhambha Surbharti Prakashan, Varanasi, 2014, page- 171.

19. Agnivesh, Annapaanvidhi Adhyaay, Sutra Sthan, Charak Samhita with Chakrapani Teeka, ed. Yadavji Trikam Ji, Ist edition, Chaukhambha Surbharti Prakashan, Varanasi, 2014, page- 171.

20. Agnivesh, Annapaanvidhi Adhyaay, Sutra Sthan, Charak Samhita with Chakrapani Teeka, ed. Yadavji Trikam Ji, Ist edition, Chaukhambha Surbharti Prakashan, Varanasi, 2014, page- 171.

21. Sharangdhar, Kwath Kalpana Adhyay, Madhyam Khand, Sharangdhar Samhita with Dipika and Gudaartha Dipika Commentary, editor Vidyasagar Pandit Parshuram Shashtri, Chaukhambha Surbharti Prakashan, Varanasi, 2013, page- 164-170.

22. Agnivesh, Tasyashitiya Adhyaay, Sutra Sthan, Charak Samhita with Chakrapani Teeka, ed. Yadavji Trikam Ji, Ist edition, Chaukhambha Surbharti Prakashan, Varanasi, 2014, page- 45-46.

23. Bhavprakash, Haritakyadi Varga, Bhavprakash Nighantu, commentary by K.C. Chunekar, Varansi, Chaukhambha Bharti Academy, 2013, page- 14.

24. Agnivesh, Dirghanjeevitiya Adhyaay, Sutra Sthan, Charak Samhita with Chakrapani Teeka, ed. Yadavji Trikam Ji, Ist edition, Chaukhambha Surbharti Prakashan, Varanasi, 2014, page-22. 